\title{
Ecosystem goods and services from Manila clam culture in Puget Sound: a modelling analysis
}

\author{
Camille Saurel $^{1}$, João G. Ferreira ${ }^{2, *}$, Dan Cheney ${ }^{3}$, Andy Suhrbier ${ }^{3}$, Bill Dewey ${ }^{4}$, \\ Jonathan Davis $^{5}$, Jeff Cordell ${ }^{6}$ \\ ${ }^{1}$ Danish Shellfish Center, DTUAqua, Øroddevej 80, 7900 Nykøbing Mors, Denmark \\ ${ }^{2}$ Dept. Environmental Science and Engineering, Faculty of Sciences and Technology, New University of Lisbon, \\ 2829-516 Monte de Caparica, Portugal \\ ${ }^{3}$ Pacific Shellfish Institute, 509 12th Ave SE, Olympia, WA 98501, USA \\ ${ }^{4}$ Chuckanut Shellfish Inc., 704 E. Hiawatha Blvd., Shelton, WA 98584, USA \\ ${ }^{5}$ Baywater Inc, 15425 Smoland Lane NE, Bainbridge Island, WA, 98110-1040 USA \\ ${ }^{6}$ University of Washington, School of Aquatic and Fisheries Sciences (SAFS), Box 355020, Seattle, WA 98195-5020, USA
}

\begin{abstract}
The carrying capacity of a 2.4 ha Manila clam Venerupis philippinarum farm, using mechanised harvesting in North Puget Sound, WA, USA, was determined by means of an ecological model; the results were also scaled to Puget Sound as a whole. An individual Manila clam growth model was developed, calibrated and validated for the commercial farm, together with a macroalgal model to simulate fouling of the predator nets by seaweeds. Both models are based on our previously developed generic frameworks for bivalves (AquaShell) and seaweeds (AquaFrond). For the most part, equations are taken or adapted from the literature and parameterised for the studied site. The individual models were incorporated into the Farm Aquaculture Resource Management (FARM) model to simulate the production cycle, environmental effects and economic optimisation of culture. Both the individual and farm-scale models are built using object-oriented programming. Potential effects of clam production on seaweed growth were analysed and found to be about $10 \%$ above background. The FARM model was also used to classify the farm area with respect to its eutrophication status, by applying the Assessment of Estuarine Trophic Status (ASSETS) model. Farm production ranging from 32 to $45 \mathrm{t}$ of clams per year is well reproduced by the model. Harvest yield is very sensitive to mortality, and profitability is very sensitive to seed costs. Manila clam culture provides a potential nutrient credit trading value of over US $\$ 41000$ per year, over 1000 Population-Equivalents (PEQ, i.e. loading from humans or equivalent loading from agriculture or industry) with respect to eutrophication control. The potential income would add $21 \%$ to the annual profit (\$194900) from clam sales. A scaling exercise to the whole of Puget Sound is in reasonable agreement with declared production (difference of $16 \%$ ), and suggests that clams provide a significant ecosystem service, of the order of 90000 PEQ per year.
\end{abstract}

KEY WORDS: Manila clam · Aquaculture $\cdot$ Sustainability $\cdot$ Ecological model $\cdot$ Culture practice FARM model

\section{INTRODUCTION}

Aquaculture production of high quality proteinbased food is needed to meet the increasing world demand for seafood products (Costa-Pierce 2002, Godfray et al. 2010). However, in order to grow sus-

${ }^{*}$ Corresponding author: joao@hoomi.com tainably, the aquaculture industry must comply with a broad range of natural and social conditions (Jonell et al. 2013, Maltby 2013): (1) social acceptance; (2) comprehensive governance with consistent environmental regulations and sustainable culture practices; (3) new culture technologies; (4) stakeholder collabo-

(C) The authors 2014. Open Access under Creative Commons by Attribution Licence. Use, distribution and reproduction are unrestricted. Authors and original publication must be credited. 
ration and incentives and (5) compliance of farmers with best management practices, and improved ecocertification across local to international scales.

Aquaculture is the fastest growing food production sector in the world, with a $650 \%$ increase in the last 30 yr. Sixty million tonnes per year of aquatic products now come from aquaculture, $88 \%$ of which originate in Asia (FAO 2012). Aquaculture needs to increase to 80 million tonnes to meet the demand in fish protein from a human population expected to hit 9.3 billion by 2050 (Godfray et al. 2010, UN 2010, FAO 2012). Due to unsustainable exploitation of some of the wild stocks and increased demand for aquatic products (Jackson et al. 2001, Worm et al. 2009, Worm \& Branch 2012), aquaculture now exceeds the wild fish supply for human food (FAO 2012).

The projected yield from capture fisheries and aquaculture is realistic if (1) fisheries are sustainably managed (Merino et al. 2012), and (2) aquaculture expands following the ecosystem approach, by optimising ecological equilibrium, stakeholder wellbeing and multiple ecosystem uses (Soto et al. 2008).

In the marine environment, shellfish correspond to $75.5 \%$ of total aquaculture production, while finfish represent only $8.7 \%$, despite the recent substantial increase in salmonid culture (FAO 2012). However, over two-thirds of aquaculture takes place in landbased ponds, for freshwater species such as tilapia and carp, and bivalve shellfish represent only $23.6 \%$ of world production, although they are one of the most sustainable forms of aquaculture animals low in the food chain that obtain their food through organic extraction (Shumway et al. 2003, Burkholder \& Shumway 2011).

In the US, legislation such as the National Aquaculture Act (1980), Clean Water Act (CWA 1972) and Coastal Zone Management Act (1972) has been followed by the National Shellfish Initiative (NSI 2011) supported by the National Oceanic and Atmospheric Administration (NOAA), which was followed by the Washington Shellfish Initiative (WSI 2011). The WSI was developed through a partnership among Washington State, tribes, shellfish restoration practitioners and the shellfish industry, with an emphasis on Puget Sound, to promote clean water with the objective of 'protecting and enhancing a resource that is important for jobs, industry, citizens and tribes'. This initiative includes industry partnerships to promote new economic opportunities, restoration and improved water quality, as well as science on the impacts of ocean acidification on shellfish recruitment.

Bivalve aquaculture may be seen as a green industry, providing ecosystem goods and services (Jackson et al. 2001, Smaal et al. 2001, Newell 2004, Coen et al. 2007, zu Ermgassen et al. 2013) that include: (1) reduction of turbidity and nutrient control through filtration of organic matter (Forrest et al. 2009, Carlsson et al. 2012, Pollack et al. 2013); (2) water quality improvement through reduction of primary eutrophication symptoms, thereby minimizing secondary symptoms such as hypoxia (Bricker et al. 2003, Ferreira et al. 2007); (3) provision of habitat for early stages of invertebrates, and food for local predators (Inglis \& Gust 2003, Dealteris et al. 2004, ŠegvićBubić et al. 2011) and (4) potential improvement of shellfish recruitment in adjacent areas, thereby helping restoration (Wilbur et al. 2005).

High shellfish culture density may, however, impact the ecosystem through food competition with wild filter-feeders (Dame \& Prins 1997) and cause shifts in the phytoplankton community (Prins et al. 1997). It may also have an indirect impact on recruitment of benthic predators (Inglis \& Gust 2003), promote seaweed fouling through nutrient release in the vicinity of the farm (e.g. Lavoie et al. 2013) and, under extreme conditions, biodeposits may result in sediment anoxia (Cranford et al. 2009).

In general, sediment organic enrichment due to shellfish farming is considered to be limited (Crawford et al. 2003, Forrest et al. 2009) farmers understand that stocking densities leading to these effects do not benefit production, due to high mortality and reduced growth rates. Shellfish growers in North America are committed to maintaining good water quality status for their growing areas (Dewey et al. 2011). In 2010, the EPA funded the Clean Samish Initiative: 'Clean Samish and Pollution Identification and Correction (PIC) Program' to improve the water quality of the bay.

Nevertheless, there is some controversy in Puget Sound concerning the use of intertidal areas (beaches) for shellfish cultivation, and licensing of new farms. Dumbauld et al. (2009) described the ecological role of bivalves on the West Coast and established that although shellfish culture may temporally enhance sediment disturbance during harvest and maintenance, and cause removal of suspended material through filtration, it introduces beneficial physical structure, in a similar way to seagrass beds, and is unlikely to have a negative impact on the well-flushed waters of Puget Sound. At the farm, an increased number of certain species under netting has been observed, as it provides protection not only to the cultured species but to other bivalves as well.

In this work, we explored various aspects of carrying capacity and sustainability of state-of-the-art 
shellfish farming, using as an example Manila clam bottom cultivation at the Chuckanut Shellfish farm in Samish Bay, North Puget Sound, WA, USA.

The well-tested (Ferreira et al. 2009, 2012, Nunes et al. 2011) Farm Aquaculture Resource Management (FARM) model was applied to:

(1) Simulate the operations of the Chuckanut Shellfish farm, such as the effect of bed preparation, predator net fouling and clam harvest

(2) Examine the environmental effects and economic externalities of cultivation

(3) Determine the appropriate shellfish density for optimal carrying capacity

(4) Provide information on culture technologies such as mechanical culture practice, with outreach to Manila clam farmers in the region, and other shellfish farmers and harvesters in the US and worldwide.

\section{MATERIALS AND METHODS}

\section{Clam culture in the Pacific NW United States}

On the US West Coast, aquaculture started in the late 1800s (Dumbauld et al. 2009); Manila clams Venerupis philippinarum and Pacific oysters Crassostrea gigas were introduced in the 1930s (Chew 1989), and at present clam culture occurs mainly in Washington State, with an annual production of approximately $4500 \mathrm{t}$ in 2009, while very little is produced in California (336 t). Canada produced 1113 t in 2012 (www.dfompo.gc.ca/stats/aqua/aqua12-eng.htm, Pacific Coast Shellfish Growers Association 2012).

\section{Study site}

The Chuckanut Shellfish farm in Samish Bay, (Washington State, USA), a Puget Sound embayment in the Salish Sea, (Fig. 1) developed innovative techniques and practices about a decade ago, aiming to promote sustainable aquaculture - Manila clams are planted under predator nets, which are mechanically deployed and defouled. Clam harvesting is also mechanised (Figs. 2-4). The detail of the farm practice is described in Table 1 and Fig. 4. The harvest at Chuckanut is more efficient (over 10 times faster) and cost-effective (70\% cheaper) than manual harvesters using short-handled rakes; cost comparisons account for both amortization of plant and equipment and marginal costs (B. Dewey pers. obs.).

Experiments were conducted at the 2.6 ha ( 6.5 acres) currently farmed at Chuckanut. Intertidal bottom culture of Manila clams uses $70 \%$ of the farm area, while

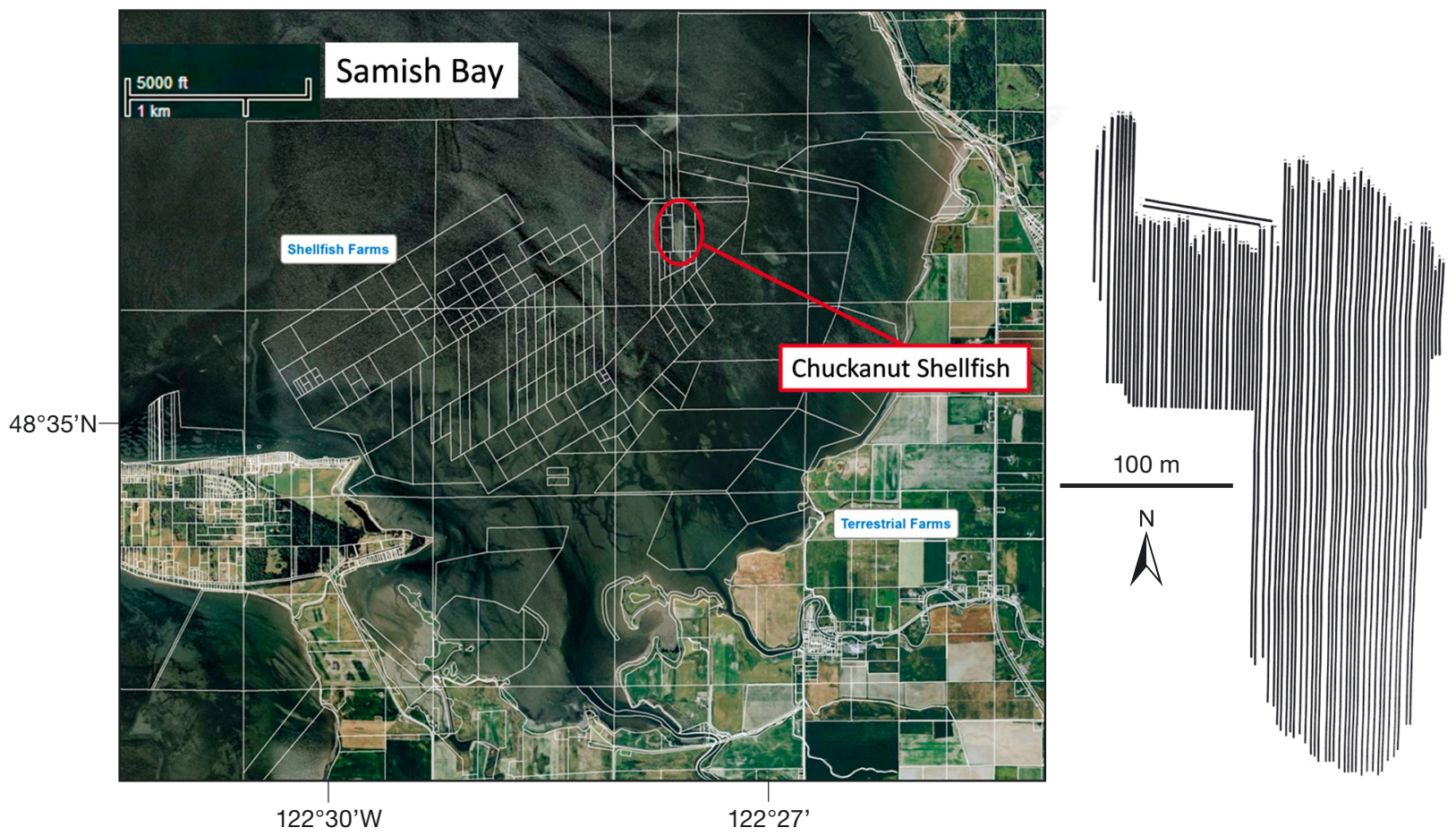

Fig. 1. Chuckanut Shellfish farm location in Samish Bay, northern part of Washington State, USA. (Right) Farm layout, lines represent the cultivated strips. Sampling areas for water quality, clam production and reference sites are contained within or are adjacent to the farm layout 


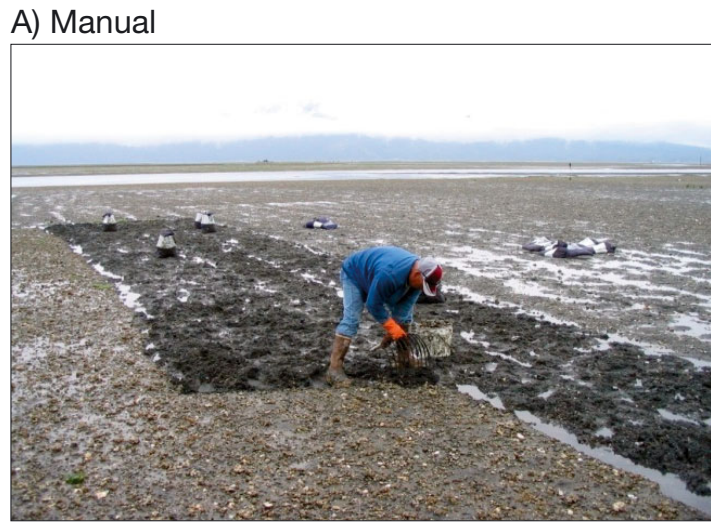

B) Mechanical
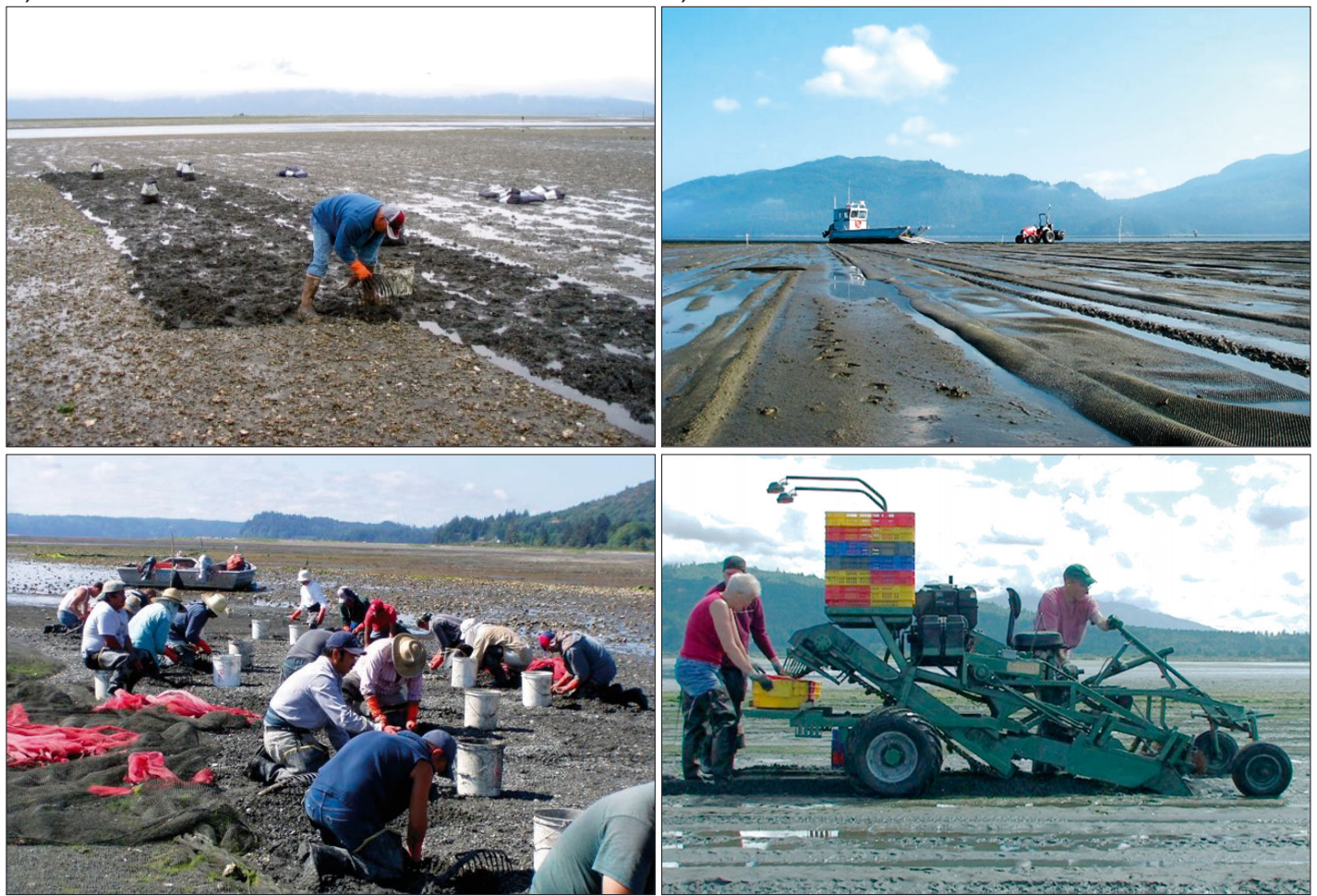

Fig. 2. (A) Manual versus (B) mechanical intertidal bottom culture of Manila clams in Samish Bay (Photo courtesy B. Dewey)

\section{A) Fouling}

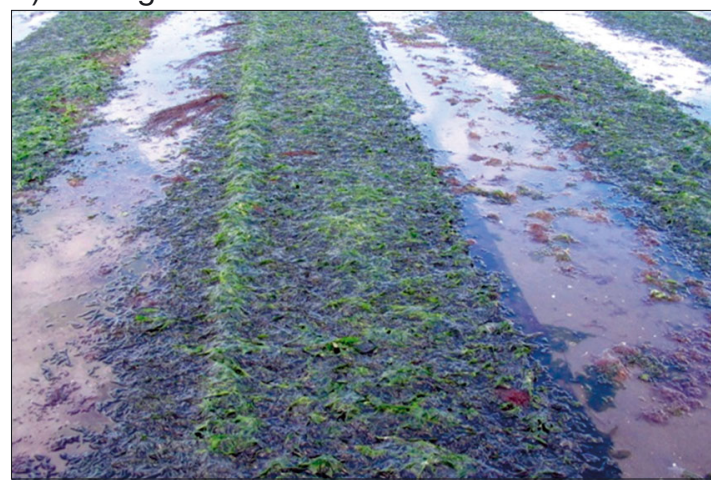

\section{B) Sweeping}

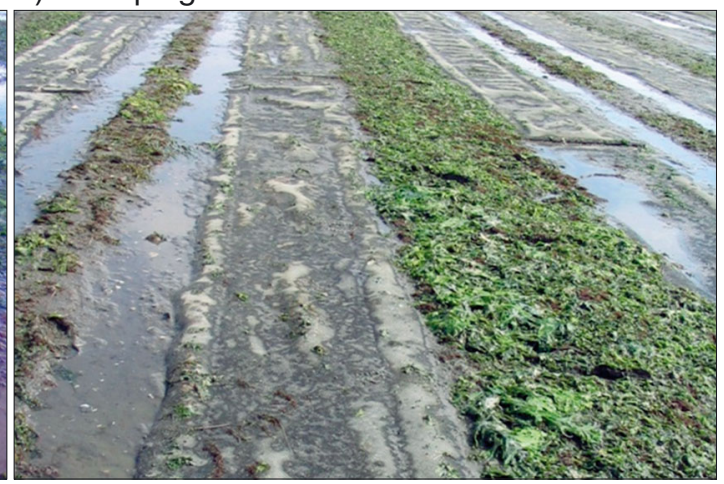

Fig. 3. (A) Predator nets strips of Manila clam bottom culture fouled by algae are swept mechanically and (B) removed algae are left in the corridors between the net strips (Photo courtesy B. Dewey)

the remaining $30 \%$ forms aisles between cultivated rows. Predator nets ( 90 to $460 \mathrm{mlength}, 1.2 \mathrm{~m}$ width) are deployed in strips, buried along the edges and fixed to the sediment with large steel staples; clam seed is then planted within the strips, at a density of 750 ind. $\mathrm{m}^{-2}$ (70 ind. $\mathrm{ft}^{-2}$ ). Fouling occurs mainly through attachment and growth of green algae (e.g. Ulva sp.) on the predator nets, boosted by the available substrate and by the supply of dissolved nutrients.

The animals are supplied by certified high health hatcheries and harvested during the third year after seeding. Marketable size is reached after $2 \mathrm{yr}$, but since the clams are marketed by the pound, the extra weight gained by allowing a third year of growth warrants the additional growing season. The shellfish are cultivated as separate year classes in different sections of the farm, allowing for an annual harvest. As a consequence, approximately one third of the total area is harvested every year, and subsequently reseeded (Fig. 4). The reported harvest ranges from 30 to $45 \mathrm{t} \mathrm{yr}^{-1}$ (70 000 to $100000 \mathrm{lb} \mathrm{yr}^{-1}$ ).

Water quality data, morphometry, culture practice and appropriate economic indicators required to run and validate the local-scale models were obtained 


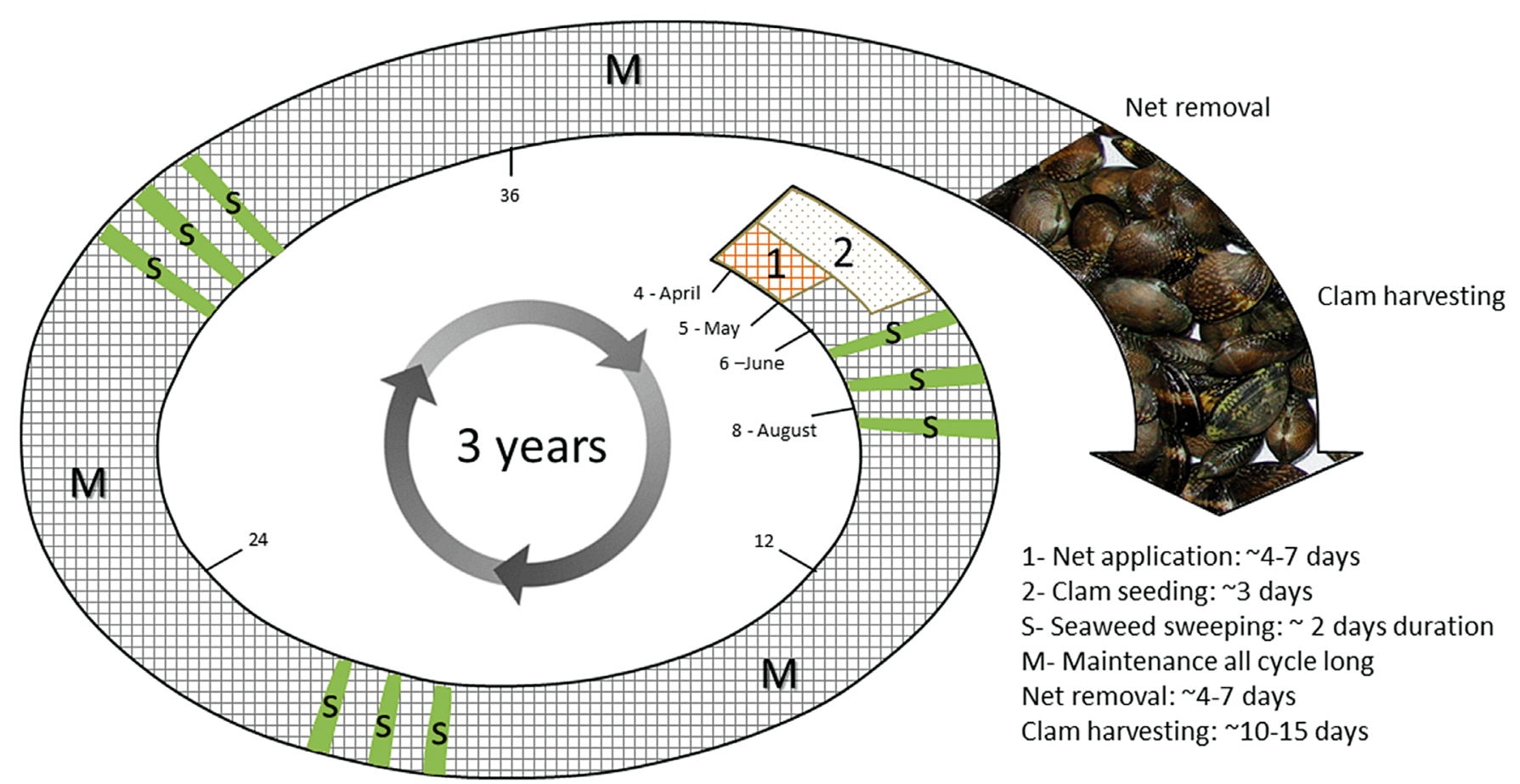

Fig. 4. Typical production cycle of Manila clam at Chuckanut farm using mechanized devices. Maintenance occurs all year long for seaweed sweeping and net positioning

Table 1. Culture practice for Chuckanut Shellfish farm

\begin{tabular}{|c|c|}
\hline Type & Descriptors \\
\hline $\begin{array}{l}\text { Farm location } \\
\text { and extension }\end{array}$ & $\begin{array}{l}\text { Location: } 48.5^{\circ} \mathrm{N}, 122.5^{\circ} \mathrm{W}, 2.4 \text { ha } \\
\text { ( } 70 \% \text { cultivated) on strips for } 3 \\
\text { different year classes (annual rota- } \\
\text { tion); intertidal, } 3 \mathrm{~m} \text { water depth. } \\
\text { Length: } 300 \mathrm{~m} \text {; width: } 75 \mathrm{~m}\end{array}$ \\
\hline Culture practice & $\begin{array}{l}\text { Bottom culture under nets; seeding } \\
\text { day: } 200 \text {; culture cycle: } 1180 \mathrm{~d} \text {; } \\
\text { mortality: } 50 \% \text {; seed weight: } 0.2 \mathrm{~g} \\
(3.2-3.5 \mathrm{~mm}) \text {; seed density: } \sim 750 \mathrm{~m}^{-2} \text {; } \\
\text { minimum harvest weight: } 18 \mathrm{~g} \text { total } \\
\text { fresh weight (TFW) }\end{array}$ \\
\hline Environment & $\begin{array}{l}\text { Semi-diurnal tidal cycle, current } \\
\text { speeds generated by peak spring and } \\
\text { peak neap speeds ( } 0.2 \text { and } 0.1 \mathrm{~m} \mathrm{~s}^{-1} \\
\text { respectively). Tidal range, spring and } \\
\text { neap: } 3 \text { and } 2 \text { m respectively }\end{array}$ \\
\hline Water quality & $\begin{array}{l}\text { Monitoring salinity, temperature, } \\
\text { chlorophyll, detritus, total particulate } \\
\text { matter }\end{array}$ \\
\hline Economics & $\begin{array}{l}\text { Seed cost: US } \$ 4 \text { per } 1000 \text {; sale } \\
\text { value to farm at harvest: } \$ 2.33 \text { per lb; } \\
\text { annual yield: } 32 \text { to } 45.5 \mathrm{t} \mathrm{TFW}\end{array}$ \\
\hline Seaweed fouling & $\begin{array}{l}\text { Macroalgal biomass set initially in } \\
\text { model at } 10 \mathrm{~g} \text { dry weight } \mathrm{m}^{-2} \text {; sweep- } \\
\text { ing assumed to take place mid-year } \\
\text { every year }\end{array}$ \\
\hline
\end{tabular}

through monitoring programmes for the farm and surrounding area.

Water temperature was recorded continuously during 2011 and 2012, using an Onset temperature data logger placed at the northern end of the farm. Water quality parameters were recorded by 2 YSI 6600 data sondes measuring temperature, $\mathrm{pH}$, dissolved oxygen (DO), salinity, fluorescence calibrated to chlorophyll a (chl a) concentration and depth. One YSI data sonde was positioned at the centre of the farm and the other sonde just outside the farm's SE corner to monitor water flowing over the farm (SE to NW on the ebb and NW to SE on the flood). These units were deployed at 3 separate occasions in 2011 for 2 to 4 wk periods at both spring and neap tides in transition from spring to neap, to monitor spring and summer conditions.

Current velocity was measured with a SonTek Argonaut ADV (Acoustic Doppler Velocimeter) probe placed at the centre of the farm, recording water movement just above the sediment during ebb tides. This sonde was deployed in the summers of 2011 and 2013 for 1 to 2 wk at a time. Additionally, quadruplicate water samples were collected monthly just outside the farm at the NW and SE corners, and at the centre of the farm during spring, summer and fall of 2011 and 2012. These were analyzed for nutrients, chl $a$, particulate organic carbon/particulate nitrogen (POC/PN) and total particulate matter (TPM). 
Average Manila clam densities, size ranges and macroalgal biomass were assessed monthly during the spring, summer and early fall of 2011 and 2012, and once during the winter of 2012 to 2013. Random $0.25 \mathrm{~m}^{2}$ quadrats were taken on transects that ran from the SW to the NE corners of the farm, collecting at least 10 samples during each sampling period. Stocking density, weight (total fresh weight and tissue dry weight) and length of clams and macroalgal dry weight were determined.

Seven benthic cores were sampled just before harvest, and 1 to $2 \mathrm{~d}$ after harvest, on 3 different plots at the centre and northern edges of the farm, on different dates (July and August 2011, May 2012). Hand harvest impact, benthic community composition and macrofauna were compared to mechanical harvest.

\section{Model development, implementation and validation}

Manila clam individual growth model

Experimental growth data (2009 to 2011) from the Samish Island site were used to calibrate and validate a Manila clam model based on the generic AquaShell ${ }^{\mathrm{TM}}$ framework for bivalves (e.g. Silva et al. 2011, Ferreira et al. 2012). Functions for key physiological processes specific to Manila clam follow Defossez \& Daguzan (1995), Flye Sainte Marie et al. (2007), and Walne (1972); formulations for morphometric relationships were obtained in this work.

The model simulates changes in individual weight, expressed as tissue dry weight and scaled to total fresh weight (with shell) and in shell weight scaled to shell length. The model is driven by relevant physical and biogeochemical components, i.e. allometry, total particulate matter, temperature and salinity, together with phytoplankton and detritus
(Table 2); Clearance rate is a function of allometry $\left(\mathrm{CR}_{\mathrm{m}}\right), \mathrm{TPM}\left(\mathrm{CR}_{\mathrm{TPM}}\right)$ and water temperature $\left(\mathrm{CR}_{\mathrm{t}}\right)$ (Eq. 1-3); the model additionally provides environmental feedbacks for particulate organic waste (faeces and pseudofaeces) and excretion of dissolved substances.

The effects of allometry of Manila clam dry weight and environmental conditions were modelled as below:

$$
\mathrm{CR}_{\mathrm{m}}=\mathrm{a} \times W^{b} \times h
$$

where (modified from Flye Sainte Marie et al. 2007) $\mathrm{CR}_{\mathrm{m}}$ is the clearance rate as a function of individual dry weight (DW) $\left(\mathrm{l} \mathrm{h}^{-1}\right), a$ is the allometric function parameter $=20.049$ (no unit), $b$ is the allometric func-

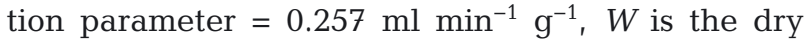
weight of the animal in grams and $h$ is the conversion factor $=6 \times 10^{-4}$.

Clearance rate as a function of individual weight was used to model the effect of TPM (Eq. 2):

$$
\left\{\begin{array}{c}
\text { if } \mathrm{TPM}<\mathrm{TPM}_{\mathrm{m}} \rightarrow \mathrm{CR}_{\mathrm{TPM}}=\mathrm{CR}_{\mathrm{m}} \\
\text { if } \mathrm{TPM}>\mathrm{TPM}_{\mathrm{t}} \rightarrow \mathrm{TPM}_{\mathrm{o}}=\mathrm{TPM} \times C \\
\text { if } \mathrm{TPM}>\mathrm{TPM}_{\mathrm{m}} \rightarrow \mathrm{CR}_{\mathrm{TPM}}=\mathrm{CR}_{\mathrm{m}} \times \frac{\mathrm{TPM}}{\mathrm{TPM}_{\mathrm{o}}} \times \exp \left(1-\frac{\mathrm{TPM}}{\mathrm{TPM}_{\mathrm{o}}}\right)
\end{array}\right\}
$$

where (modified from Defossez \& Daguzan 1995) $\mathrm{CR}_{\mathrm{TPM}}$ is the clearance rate as a function of TPM (l ind.$^{-1} \mathrm{~d}^{-1}$ ), TPM is the total particulate matter (mg $\left.\mathrm{l}^{-1}\right), \mathrm{TPM}_{\mathrm{o}}$ is the TPM optimum $\left(\mathrm{mg} \mathrm{l}^{-1}\right), \mathrm{TPM}_{\mathrm{t}}$ is the TPM threshold $=100 \mathrm{mg} \mathrm{l}^{-1}, \mathrm{TPM}_{\mathrm{m}}$ is the TPM maximum $=175 \mathrm{mg} \mathrm{l}^{-1}$ and $C$ is the constant $=0.8$. The effect of temperature $(T)$ on $\mathrm{CR}_{\mathrm{TPM}}$ was modelled as a Gaussian curve when $\mathrm{CR}$ is above or below the optimal temperature $\left(T_{\mathrm{o}}\right)$ of $15^{\circ} \mathrm{C}$ :

$$
\mathrm{CR}_{\mathrm{t}}=\mathrm{CR}_{\mathrm{TPM}} \times \frac{T}{T_{\mathrm{o}}} \times \exp \left(1-\frac{T}{T_{\mathrm{o}}}\right)
$$

Table 2. Data used to run the Manila clam AquaShell individual model ${ }^{\mathrm{a}}$, and the FARM model ${ }^{\mathrm{b}}$ for simulation of farm-scale pro-

\begin{tabular}{|c|c|c|c|c|c|c|c|}
\hline Day & $\begin{array}{c}\text { Temperature } \\
\left({ }^{\circ} \mathrm{C}\right)\end{array}$ & $\begin{array}{l}\text { Salinity } \\
\text { (psu) }\end{array}$ & $\begin{array}{l}\text { Chlorophyll a } \\
\quad\left(\mu \mathrm{g} \mathrm{l}^{-1}\right)\end{array}$ & $\begin{array}{c}\mathrm{POM} \\
\left(\mathrm{mg} \mathrm{l}^{-1}\right)\end{array}$ & $\begin{array}{c}\text { TPM } \\
\left(\mathrm{mg} \mathrm{l}^{-1}\right)\end{array}$ & $\begin{array}{c}\mathrm{DO}^{\mathrm{b}} \\
\left(\mathrm{mg} \mathrm{l}^{-1}\right)\end{array}$ & $\begin{array}{c}\mathrm{DIN}^{\mathrm{b}} \\
\left(\mu \mathrm{mol} \mathrm{l}^{-1}\right)\end{array}$ \\
\hline 165 & 11 & 35 & 4.2 & 2.6 & 8.1 & 6.0 & 2 \\
\hline 210 & 12 & 35 & 4.9 & 2.8 & 7.5 & 7.5 & 4 \\
\hline 240 & 13 & 35 & 2.5 & 1.7 & 4.3 & 6.0 & 7 \\
\hline 270 & 12 & 35 & 3.9 & 2.7 & 14.7 & 6.5 & 5 \\
\hline 330 & 7 & 35 & 1.5 & 1.3 & 4.1 & 8.0 & 10 \\
\hline
\end{tabular}
duction and environmental effects (starting total fresh weight [TFW] $0.65 \mathrm{~g}$, starting date mid-July, cultivation period $1180 \mathrm{~d}$ ). POM: particulate organic matter, TPM: total particulate matter; DO: dissolved oxygen; DIN: dissolved inorganic nitrogen 
where (modified from Walne 1972, Sobral \& Widdows 1997) $C R_{t}$ is the clearance rate as a function of temperature $\left(1\right.$ ind. $\left.{ }^{-1} \mathrm{~d}^{-1}\right), T_{\mathrm{o}}$ is optimal water temperature $=15{ }^{\circ} \mathrm{C}$ and $T$ is the water temperature $\left({ }^{\circ} \mathrm{C}\right)$. Water temperature used for the model varied between a minimum of $7.2^{\circ} \mathrm{C}$ in winter and $13.3^{\circ} \mathrm{C}$ in summer (Table 2). Table 2 shows the environmental drivers obtained through field measurements, both in this study and other work; these were used for individual model runs, and subsequently for simulations at the farm scale.

\section{Seaweed growth model}

A macroalgal individual growth model was implemented to simulate fouling of predator nets by seaweeds. The model is adapted from Nobre et al. (2005), and uses a cell quota formulation (Droop 1970, Eq. 4). This approach was chosen since single-step kinetics are not a good model for seaweed growth (e.g. Solidoro et al. 1997) because they fail to account, for example, for the fact that production occurs even when dissolved nutrients are depleted. The left term (before the multiplication sign) is the standard Michaelis-Menten formulation, which is often used for primary production modelling of phytoplankton, i.e. the nutrient $(S$ ) uptake regulates the rate $\mu$, where $\mu_{\max }$ is the potential (i.e. light-dependent production).

Droop's equation, and subsequent adaptations e.g. by Solidoro et al. (1997), make that uptake rate regulate the quota of nutrients in the cell (in this case in the seaweeds), which is the whole first term, and the second term uses that quota, $Q$, to reduce the potential (light-limited) production, here represented as $P_{\max }$ :

$$
\frac{\mathrm{d} Q}{\mathrm{~d} t}=\frac{\mu_{\max } S}{k_{s}+S} \cdot \frac{q_{\max }-Q}{q_{\max }-q_{\min }}-P_{\max } \cdot \frac{Q-q_{\min }}{q_{\max }-k_{c}} \cdot Q
$$

where $Q$ is the cell quota $\left(\mathrm{mgN} \mathrm{g} \mathrm{DW}{ }^{-1}\right), \mu_{\max }$ is the maximum dissolved inorganic nitrogen (DIN) uptake rate from the water column $\left(\mathrm{mgN} \mathrm{gDW}^{-1} \mathrm{~d}^{-1}\right), S$ is the DIN concentration $\left(\mu \mathrm{mol} \mathrm{l}^{-1}\right), k_{s}$ is the half-saturation constant for DIN $\left(\mu \mathrm{mol} \mathrm{l}^{-1}\right), q_{\max }$ is the maximum DIN

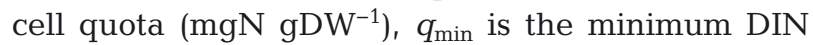
cell quota $\left(\mathrm{mgN} \mathrm{gDW}^{-1}\right), P_{\max }$ is the maximum production rate $\left(\mathrm{d}^{-1}\right)$ and $k_{c}$ is the nitrogen cell quota for growth $\left(\mathrm{mgN} \mathrm{gDW}^{-1}\right)$.

Once the nets are swept of seaweed, $\mathrm{N}$ uptake from macroalgae is excluded from the FARM model since only local processes are considered; i.e. seaweeds that are lost from the model domain are by definition not explicitly factored in subsequent calcu- lations, except insofar as the nutrient drivers of the model reflect macroalgal decomposition and mineralization.

The individual growth model in Eq. (4) is used in Eq. (5) to calculate gross primary production (GPP) by scaling to the existing biomass, and net primary production (NPP) is determined according to Eq. (6):

$$
P=P_{\max } \cdot \frac{1-q_{\min }}{Q}
$$

where $P$ is the production $\mathrm{d}^{-1}$ and:

$$
\left\{\begin{array}{c}
\text { if } \mathrm{GPP}>0 \rightarrow \mathrm{NPP}=\mathrm{GPP}\left(1-R_{\mathrm{l}}+E\right) \\
\text { if } \mathrm{GPP}=0 \rightarrow \mathrm{NPP}=\mathrm{GPP}(1-E)-B \times R_{\mathrm{d}}
\end{array}\right\}
$$

where $R_{1}$ is the light respiration coefficient $=0.3 \mathrm{mgC}$ $\mathrm{gDW}^{-1} \mathrm{~h}^{-1}, E$ is the exudation coefficient $=0.02$ (no units), $B$ is the macroalgal biomass (g DW) and $R_{\mathrm{d}}$ is the maintenance respiration coefficient $=0.01 \mathrm{~d}^{-1}$. The individual growth model is forced by photosynthetically available radiation (PAR, $\mu$ mol photons $\mathrm{m}^{-2}$ $\mathrm{s}^{-1}$ ) and DIN. The farm-scale model (see below) calculates the depth of the clam farm at every time step, and determines PAR attenuation in the water column due to suspended particulate matter when the farm is immersed.

\section{Farm-scale model}

The model simulates processes at the farm-scale by integrating a set of different sub-models: (1) hydrodynamic and particle settling (for suspension culture), (2) biogeochemical, (3) shellfish and finfish growth models and (4) ASSETS eutrophication screening model (Bricker et al. 2003). Three different types of outputs may be obtained with FARM, focusing on people (production), planet (environmental externalities) and profit. The FARM outputs are production, average physical product (a proxy for return on investment), income, expenditure, gross profit, biodeposition, nutrient emission and eutrophication assessment. A marginal analysis of optimal stocking density (Ferreira et al. 2011) is obtained by increasing seeding density (see details in Fig. 11) with the known values for input ( $P_{\mathrm{i}}=40$ USD for $1 \mathrm{~kg}$ of seed in this study) and output $\left(P_{\mathrm{o}}=4\right.$ USD for $1 \mathrm{~kg}$ of harvested clam) costs, and simulating the corresponding potential harvest. The Value of Marginal Product (VMP) is then used to calculate the Marginal Physical Product (MPP) which corresponds to the first derivative of the production (Total Physical Product, TPP) curve, and yields the point at which profit maximization occurs (Jolly \& Clonts 1993, Ferreira et al. 2007). 
The individual Manila clam model was incorporated into the FARM model, and locally measured environmental drivers, together with culture practice established both through the farm owner and in situ work (Table 1 \& 2), were used to assess actual and potential production, economic performance and environmental externalities.

The FARM model was modified to simulate macroalgal production on the predator nets using a population, size-based, dynamics model (Nobre et al. 2005), driven by the individual growth model described above and by seaweed mortality. Additionally, the seaweed simulation accounts for the sweeping of predator nets at regular intervals (Fig. 3), which is normal operating procedure on the farm - an excessive build-up of seaweed biomass may lead to high clam mortality due to sediment hypoxia.

The macroalgal model was initialized with a standing stock of $5 \mathrm{~g} \mathrm{DW}$, based on measured data, and validated against peak biomass measured as part of the field data collection, using the $90^{\text {th }}$ percentile of $47.4 \mathrm{~g} \mathrm{DW}$ as a reference point.

\section{RESULTS AND DISCUSSION}

The results from the clam individual growth model together with the mass balance over a growth cycle are briefly reviewed and are followed by the FARM model results. Finally, a scaling exercise of the services provided by Manila clam for the whole of Puget Sound is presented.

\section{Individual clam growth model}

The simulated growth of an individual Manila clam is shown in Fig. 5, using 3 key indicators: shell length, total fresh weight and tissue dry weight. The individual model reproduced the weight increase in the growing season, and the negative scope for growth in winter due to both low temperature and food concentrations. The model predicted a final shell length of $46.5 \mathrm{~mm}$, a total fresh weight of $27 \mathrm{~g}$ and a tissue dry weight of $1.27 \mathrm{~g}$ at Day 1020. This is in good agreement with the field data for the same period, i.e. $46.7 \mathrm{~mm}, 26.6 \mathrm{~g}$ and $1.44 \mathrm{~g}$ respectively.

Validation curves for measured versus simulated shell length are also presented in Fig. 5. The normalised root mean square deviation (NRMSD) was equal to $12.7 \%$. The slope of the linear regression of the simulated versus measured shell length was close to the line of identity (Fig. 6); only 2 points were
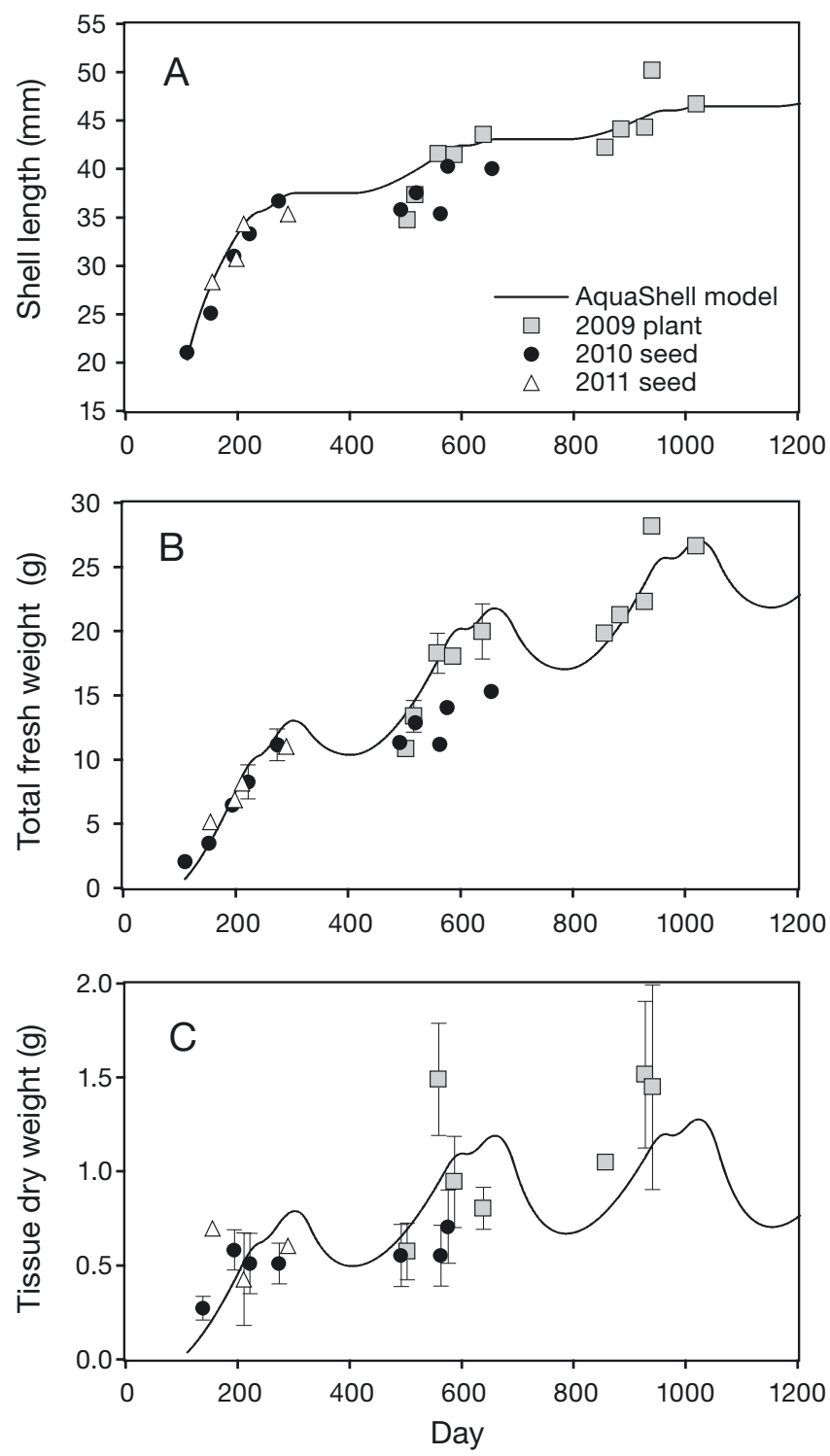

Fig. 5. Simulation of (A) shell length, (B) total fresh weight and $(\mathrm{C})$ tissue dry weight over a full growth cycle. Error bars are SD

responsible for the slight shift between the line of identity and the linear regression, and are outside the standard deviation of the average difference between simulated and observed data.

The individual model was tested in WinShell, a workbench that handles model pre- and post-processing, and generates a mass balance output for the whole culture cycle, taking into account both production and environmental effects (Fig. 7).

WinShell is not useful for analysing the cultivation of large numbers of clams, but provides a userfriendly platform to handle input and output from AquaShell, and allows the farmer to look at the 


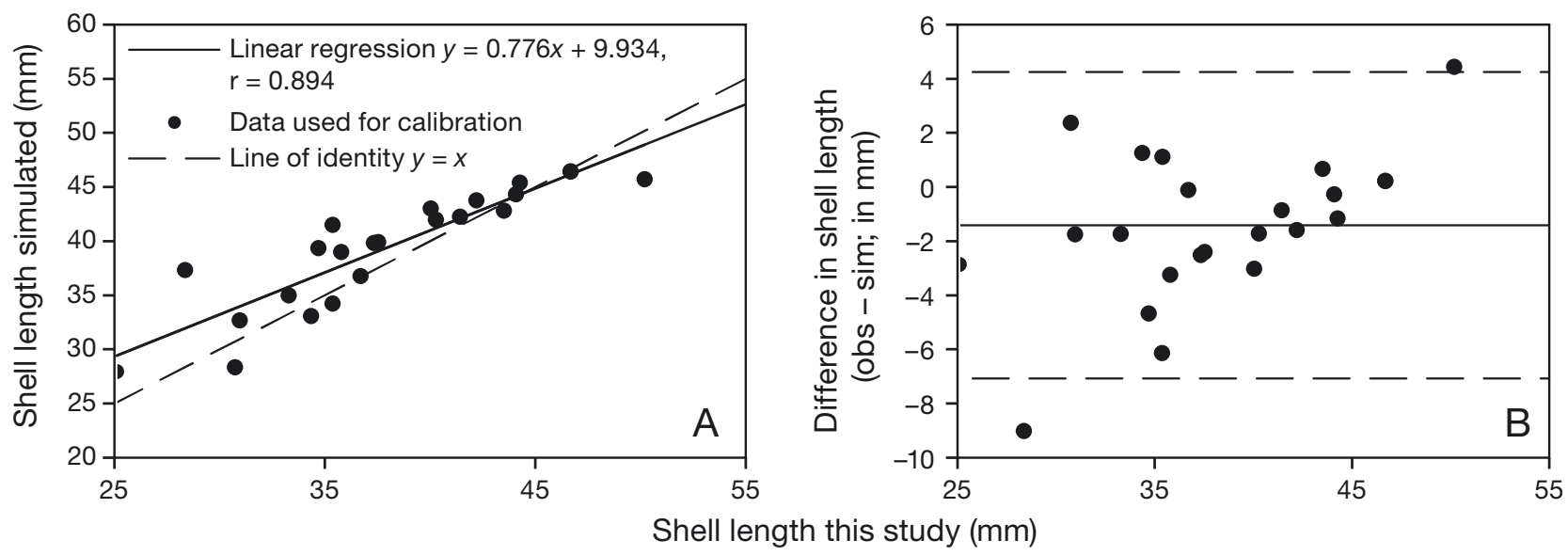

Fig. 6. (A) Shell length measured in this study versus simulated shell length for Manila clam; (B) transformed values from (A) where $x$-axis is the measured shell length and $y$-axis is the difference between the observed and simulated shell length. Horizontal line is the average difference while the dashed lines are \pm 2 SD of this difference. NRMSD $=12.7 \% \mathrm{r}^{2}=0.75$

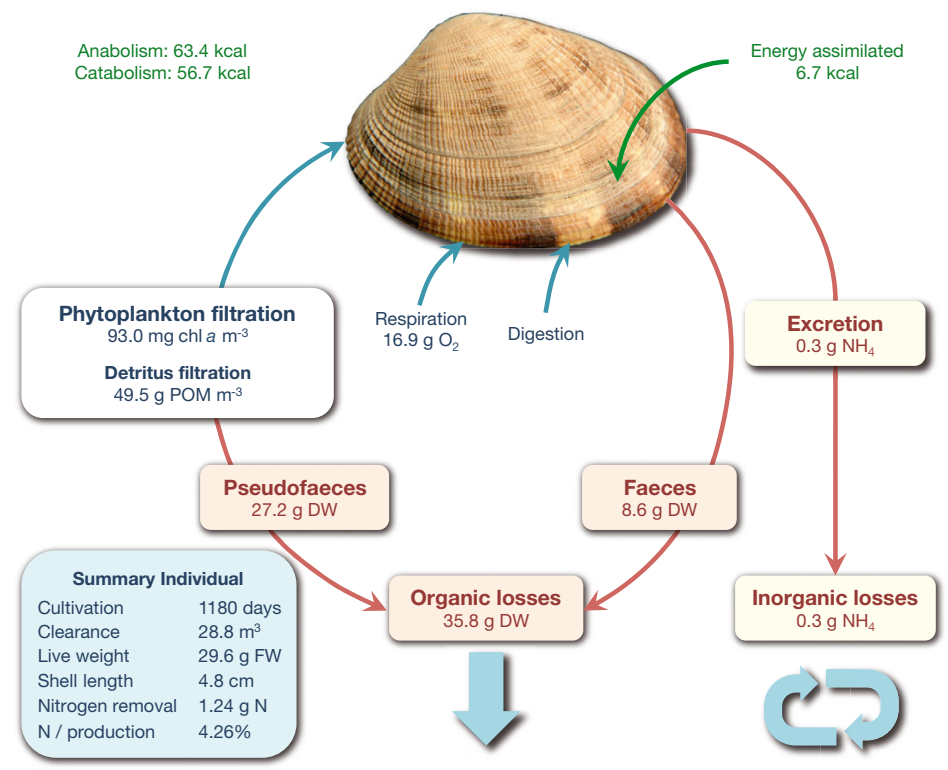

Fig. 7. WinShell mass balance results for an individual Manila clam over a full growth cycle at Chuckanut Shellfish farm. DW (FW): dry (fresh) weight; POM: particulate organic matter

growth and environmental performance of an animal for a particular set of environmental drivers. A single (modelled) clam clears almost $29 \mathrm{~m}^{3}$ (7700 US gallons) of water over the culture cycle, and removes over $1 \mathrm{~g}$ of nitrogen, more than $4 \%$ of the live weight produced.

\section{Farm-scale production, culture practice and seaweed growth}

Table 3 shows the FARM model outputs for a full culture cycle of Manila clam in the standard simula- tion. The overall outcome of the farm activity is represented in Fig. 8 as an annualized mass balance based on the $1180 \mathrm{~d}$ culture cycle.

The annual harvest of the simulated farm, with a standard seeding density of 750 ind. $\mathrm{m}^{-2}$, is about $48 \mathrm{t} \mathrm{yr}^{-1}$ (106000 lb), a reasonable match to the reported harvest of 30 to $45 \mathrm{t} \mathrm{yr}^{-1}$ (70000 to $100000 \mathrm{lb} \mathrm{yr}^{-1}$ ). Since this work was developed in close cooperation with the farm, there is a much greater confidence in comparisons of predicted and observed harvest than normally occurs when model results are matched against declared landings.

Certain types of mechanised harvesters appear to be no more disruptive to the benthos than manual harvesting (Stirling 2011). Other types, however, might have long-term effects on the environment, such as changes to benthic engineers, and indirectly birds, or via the re-suspension of anoxic sediment and modification of sediment composition (Coen 1995, Kaiser et al. 1996, Spencer et al. 1997, Pranovi et al. 2003, Badino et al. 2004, Toupoint et al. 2008, Godet et al. 2009). The modified tulip harvester used at Chuckanut Shellfish farm was not found to have negative effects on benthos or sediment quality, based on the data collected at the same time as this study. The density (log transformed data) and richness of taxa present in the reference site were superior to both hand- and mechanically-harvested sites $(p<0.001)$, but there was no significant difference at both the hand and mechanised cultivated sites.

Taxa richness for the hand-harvested site was superior prior to harvest $(p=0.028)$. The density was 
Table 3. Simulated production and environmental effects of Manila clam farming in North Puget Sound (per 1180 d cycle)

\begin{tabular}{|c|c|}
\hline Variable & Model results \\
\hline \multicolumn{2}{|l|}{ Model inputs } \\
\hline Seeding (kg total fresh weight [TFW]) per production cycle & 3375 \\
\hline \multicolumn{2}{|l|}{ Model outputs } \\
\hline \multicolumn{2}{|l|}{ Production } \\
\hline Total physical product (kg TFW) per production cycle & 157554 \\
\hline Average physical product (APP, Output/Input) & 47 \\
\hline \multicolumn{2}{|l|}{ Environmental externalities } \\
\hline Change in 90th percentile $\mathrm{NH}_{4}{ }^{+}$concentration $\left(\mu \mathrm{mol} \mathrm{l}{ }^{-1}\right)$ & 8.92 (in) -9.04 (out) \\
\hline Change in 90th percentile chlorophyll a (mg chl $\left.a \mathrm{~m}^{-3}\right)$ & 4.49 (in) -3.98 (out) \\
\hline Change in 10th percentile $\mathrm{O}_{2}$ concentration $\left(\mathrm{mg} \mathrm{l}^{-1}\right)$ & 6.17 (in) -6.10 (out) \\
\hline ASSETS eutrophication model score & No change (in to out) \\
\hline \multicolumn{2}{|l|}{ Profit and loss } \\
\hline Total income (i.e. Manila clam sales, US \$ per cycle) & 630210 \\
\hline Total marginal expenditure (i.e. seeds, US \$ per cycle) & 135000 \\
\hline Farm profit (i.e. income-expenditure, US \$ per cycle) & 495210 \\
\hline
\end{tabular}

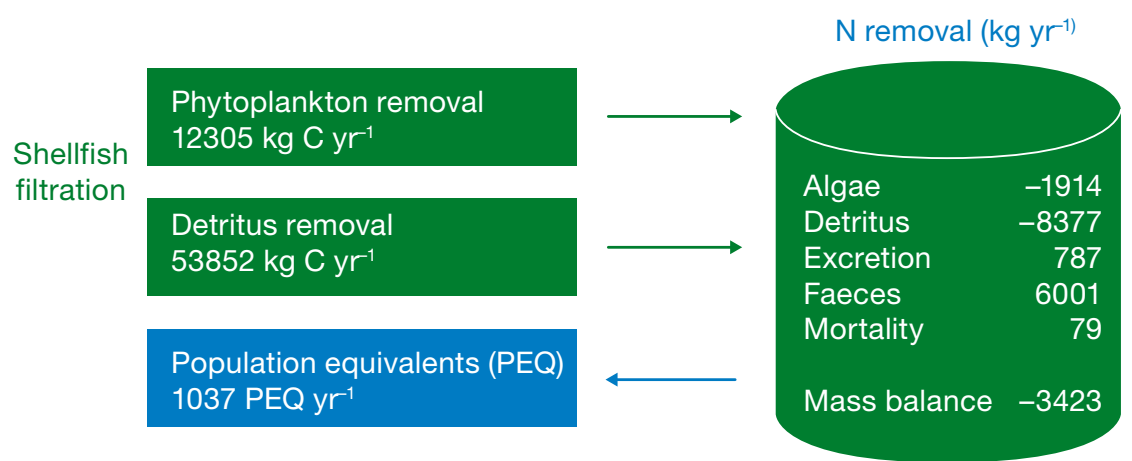

\begin{tabular}{|c|c|c|}
\hline Assets & Income & Parameters \\
\hline $\mathrm{Chla}$ & Shellfish farming income: $194 \mathrm{k} \$ \mathrm{yr}^{-1}$ & Density: \\
\hline $\begin{array}{c}\mathrm{O}_{2} \\
\text { Score }\end{array}$ & $\begin{array}{l}\text { Nutrient treatment: } \\
\text { Total income: }\end{array}$ & Cultivation period: $1180 \mathrm{~d}$ \\
\hline
\end{tabular}

Fig. 8. FARM model annualized mass balance for Manila clam culture at Chuckanut Shellfish farm (the seaweed fouling component is not included)

more variable depending on the date: July: pre- to post-harvest $p<0.001$; August: pre- to post-harvest $\mathrm{p}=0.030$, while in May there was no significant difference $(p=0.254)$.

On the other hand, there were no significant differences between the pre-mechanical versus postmechanical harvest for both density $(p=0.824)$ and taxa richness $(\mathrm{p}=0.073)$.

At Chuckanut, predator nets are deployed and kept on site during the whole culture period; they are then recycled for use in the next period. Several authors have shown that similarly deployed nets may increase concentrations of organic matter to a limited extent (Munroe \& McKinley 2007, Bendell et al. 2010), and could imply shifts in community structure (Bendell et al. 2010), but in another experiment where predator nets were placed above net bags for hard clams, they also acted as artificial reefs and increase biodiversity and provide nursery grounds through macroalgal colonisation (Powers et al. 2007).

The FARM model results suggest that there is a minimal increase in ammonia concentration in the surrounding water (Table 3), and the simulated excretion of $\mathrm{NH}_{4}^{+}$by the clams becomes a nutrient source for the seaweeds (Figs. $9 \& 10$ ). The model provides an adequate simulation of the measured biomass (Fig. 9) of macroalgae (Ulva and other genera) with a 90th percentile of $47.4 \mathrm{~g}$ DW.

The FARM model simulates sweeping at regular intervals, and the subsequent new growth of macroalgae on the nets. Currently, the swept seaweeds float away or decompose in the areas between clam rows, but Chuckanut Shellfish is working on alternatives for potential re-use of swept macroalgae. The second and third year clams are larger and excrete more ammonia, and the model adequately reflects this with higher seaweed biomass peaks. This fouling pattern with increasing clam size has been verified in loco (Dewey et al. 2013).

Fig. 10 shows the difference in fouling with and without clams, and illustrates the fact that some macroalgal colonisation would occur because of the available substrate (predator nets), even if clams were not cultivated. The increased fouling in farm sections with larger clams (higher year classes) is also shown, and reflects a greater emission of ammonia from the clam beds due to excretion by larger animals. 


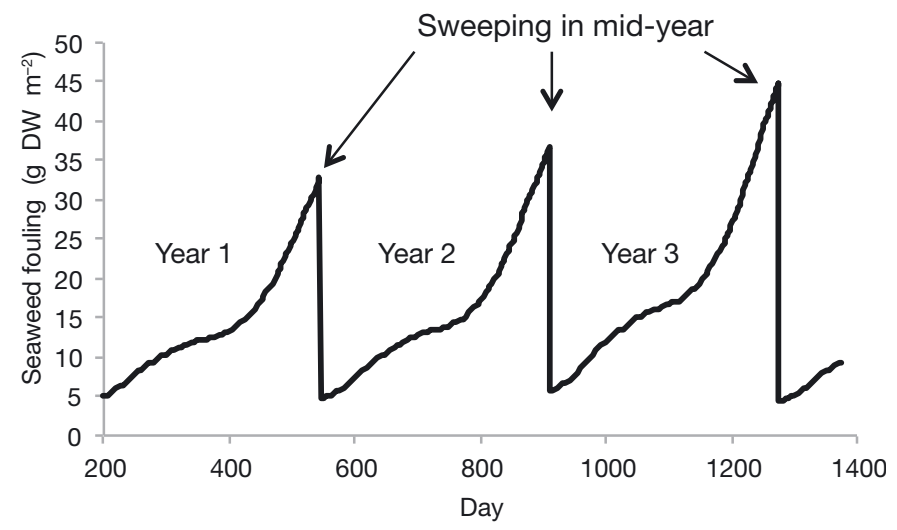

Fig. 9. Seaweed fouling on predator nets at the Chuckanut Shellfish farm; 20 onsite measurements of seaweed dry weight: 90th percentile $=47.4 \mathrm{~g}$ dry weight (DW)

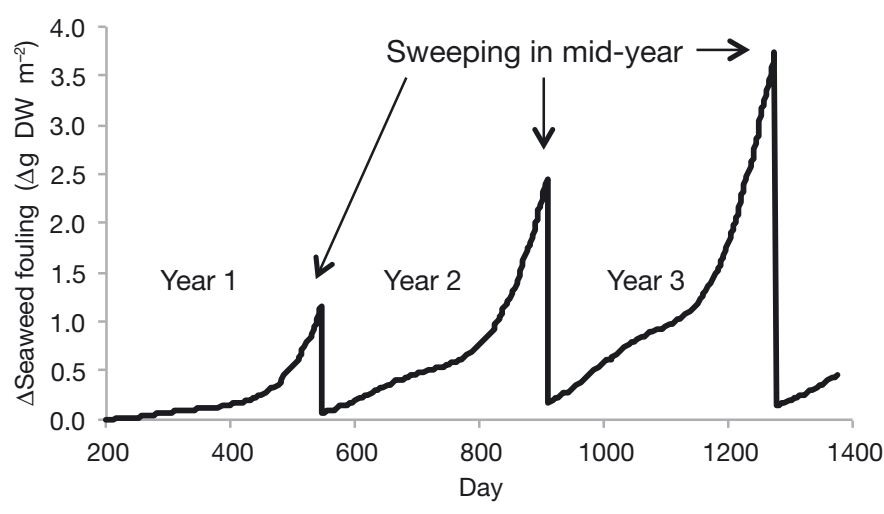

Fig. 10. Difference in seaweed fouling on predator nets at Chuckanut Shellfish farm for planted and fallow plots

The results in Table 3 additionally highlight that the effects of clam culture on DO are minimal $\left(-0.07 \mathrm{mg} \mathrm{l}^{-1}\right)$, and that there is a significant drawdown of chl $a_{1} 0.5 \mu \mathrm{g} \mathrm{l}^{-1}$, or $20 \%$ of the ambient concentration. This is an important positive externality of clam culture at Chuckanut Shellfish, since it contributes to a reduction of primary symptoms of eutrophication, and therefore short-circuits the potential development of secondary symptoms associated with organic decomposition (e.g. Bricker et al. 2003).

This raises the possibility of integrating farms such as Chuckanut Shellfish into a broader, catchmentscale nutrient management plan. For instance, nutrient credit trading is one approach used for the proposed Chesapeake Clean Water and Ecosystem Restoration Act of 2009 (H.R. 3852/S. 1816; Jones et al. 2010), aimed at creating revenue opportunities and reducing the cost associated with excess nutrient at the bay scale, and promoting the reduction of nutrient loads.

FARM not only makes it possible to simulate the total mass balance of phytoplankton and organic detritus removed, but also the monetary equivalent for nutrient removal, which in this case corresponds to over $\$ 40000$ per year $(1 \mathrm{~kg} \mathrm{~N}$ is valued at $12.4 \mathrm{USD}$ by Meybeck et al. 1989; Fig. 8). The macroalgal sweeping component is not included in this figure, and should be amended once a harvesting system is developed. Over $20 \%$ of additional income may be derived from nutrient credit trading when such a management plan is implemented in the area (Fig. 8). This figure should be seen as a minimum, since the cost of nutrient removal is largely dependent on both the sources and the methods used. Stephenson et al. (2010) estimate that a low-end cost of $73 \mathrm{USD} \mathrm{kg}^{-1}$ (33 USD lb-1) for low cost septic retirement escalates to 843-1337 USD kg-1 (383-653 USD $\mathrm{lb}^{-1}$ ) for wet ponds, and can reach a peak of $4873 \mathrm{USD} \mathrm{kg}^{-1}$ (2215 USD lb ${ }^{-1}$ ) for high cost sand filters.

A marginal analysis of optimal stocking density (Fig. 11) showed that from a food resource perspective there is scope for increasing cultivation seeding density up to $9 \mathrm{t}$ of seeds over a culture cycle, since the present value of $3.4 \mathrm{t}$ is still in the first stage of the production curve. However, high mortalities, principally due to heavy predation by Dungeness crabs Metacarcinus magister are already a significant risk factor, so changes should be effected in a precautionary manner. Moreover, lower densities also contribute to the ecological carrying capacity, through a more balanced partitioning of available food, and therefore help maintain other filter-feeding species in the farm area (only about $20 \%$ of the total area is actually farmed).

\section{Potential services provided by Manila clam in the Puget Sound}

The overall ASSETS score (Bricker et al. 2003, 2008) was in the high status category (Fig. 8), both for water entering the farm and after processing through the clam culture. Since ASSETS focuses on water column indicators ( $\mathrm{chl} a$ and DO only at the local scale), a shellfish farm will typically provide an ecosystem service with respect to chl a drawdown, provided oxygen consumption within the farm does not lead to a marked reduction in DO concentration. Our chl a simulations showed that the Chuckanut Shellfish farm does exercise top-down control of 


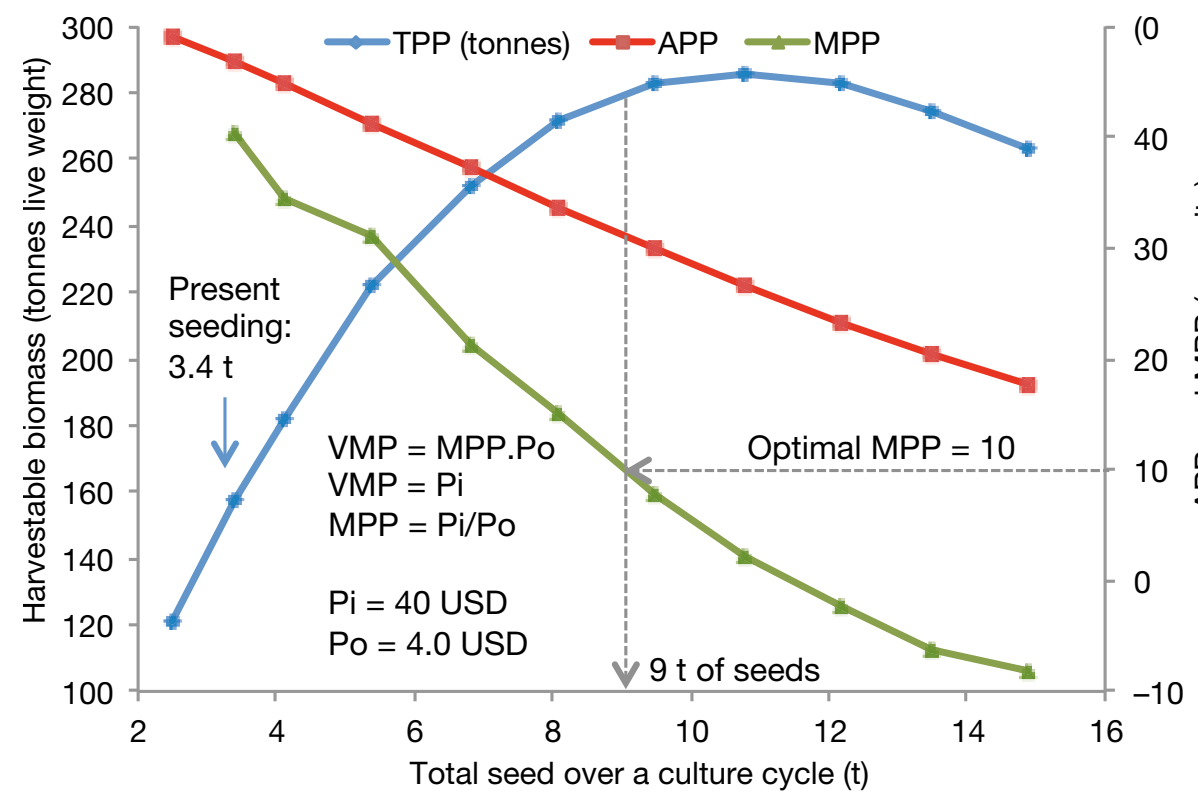

Fig. 11. Marginal analysis for Manila clam culture at Chuckanut Shellfish farm. APP: average physical product; MPP: marginal physical product; TPP: total physical product: VMP: value of marginal product; $P_{\mathrm{i}}\left(P_{\mathrm{o}}\right)$ : input (output) few small taxa and there is no natural recruitment of Manila clams in Samish Bay. Despite the previously reported caveats, and given that overall there is a low density of farms in the area which allows us to neglect farm-farm interactions, it is instructive to upscale the results from Chuckanut to the whole of Puget Sound - a comparison with declared production shows reasonable agreement, with a difference of $16 \%$. This suggests Manila clam culture in Puget Sound may provide an annual ecosystem service for eutrophication control corresponding to 90000 PEQ (1 PEQ = $3.3 \mathrm{~kg} \mathrm{~N}$ $\mathrm{yr}^{-1}$; Lindahl et al. 2005), for a production of approximately $4500{\mathrm{t} \mathrm{yr}^{-1}}^{-1}$ (Fig. 12).

\section{CONCLUSIONS}

phytoplankton, but since the inflowing water is already at a high status, the ASSETS score remained unchanged.

However, the ASSETS score for Puget Sound indicates that Hood Canal and South Puget Sound have high eutrophication symptoms, whereas other regions of the sound have an overall score of moderate, with blooms of nuisance algae that lead to shellfishery closures (Bricker et al. 1999, 2008, Trainer et al. 2007). Bricker et al. (1999) reported that eutrophication in Puget Sound was likely to worsen due to increasing human population pressure in the coastal areas.

The overall role of Manila clam culture for topdown control of eutrophication symptoms in Puget Sound was estimated through a simple budget (Fig. 12). It assumed that existing farms have the same general conditions as Chuckanut Shellfish, and the results are, therefore, indicative of conditions typically observed in Puget Sound.

However, potential interactions among farms cannot be resolved with this type of local-scale approach, and require a system-scale model, such as EcoWin.NET (e.g. Ferreira et al. 2013), that can account for food depletion effects as more shellfish farms are licensed. Moreover, an individual farm's production and environmental effects will vary as a function of the flushing rate at its location (Dumbauld et al. 2009).

The general background level of bivalve density in the culture plots is near zero with the exception of a
Chuckanut farm production is well represented by the model. Harvest yield is very sensitive to mortality, and profitability is very sensitive to seed costs. Mortality is mainly due to Dungeness crab Metacarcinus magister, white winged sea duck Melanitta fusca and surf Scoter Melanitta perspicillata predation, which can result in up to $100 \%$ crop loss when the farm is without net protection, while seed cost varies with seed size and survival (Stirling 2011).

Chuckanut Shellfish uses mechanised technologies to minimise the impact of Manila clam culture. This work showed that there were no significant beforeversus-after effects of mechanical harvest on total invertebrate densities or any individual taxa tested. The differences in effects of hand harvest on total invertebrate density were inconclusive-lower after harvest on one date, higher on another and none on the third - and the species richness was significantly lower after hand harvest.

As has been shown elsewhere (Stirling 2011), this form of mechanised harvesting appears to have a small and transient impact on the seabed. Moreover, clams are seeded as a single cohort line, with harvesting occurring only at the end of the culture cycle ( 3 yr). This time-limited substrate disturbance during harvest, together with reduced predator net maintenance for fouling control, minimises impacts on the sediment. Mechanised culture practice has been recently adopted by 2 other shellfish companies 


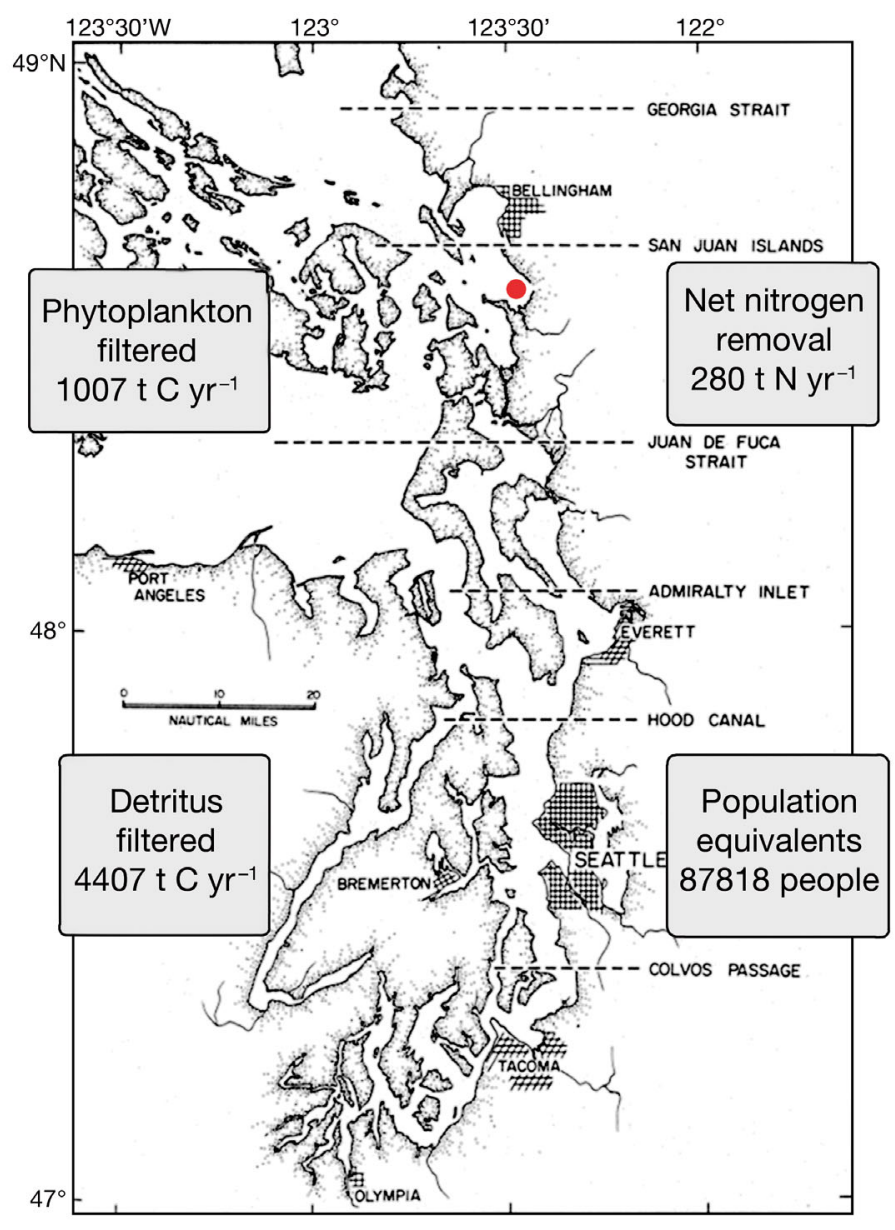

Fig. 12. Scaling of environmental externalities of clam culture at Chuckanut Shellfish farm (red dot) to the total Manila clam production in Puget Sound

in Samish Bay and mechanisation technology is responsible for an increase of almost $40 \%$ in total harvest of Manila clam in recent years, which provides both increased profits and job creation.

The results presented in this work provide valuable information for both the shellfish aquaculture industry and future management of sustainable aquaculture on the West Coast of the USA and elsewhere. These simulations fit well with the Ecosystem Approach to Aquaculture (EAA; Soto et al. 2008), and with the National and Washington Shellfish Initiative strategies (NSI and WSI 2011) blueprint for action to restore and protect Puget Sound, with a goal of a net increase of $44 \mathrm{~km}^{2}$ (10 800 acres) of harvestable shellfish by 2020.

In Puget Sound, similar eutrophication concerns to those in Chesapeake Bay (Boesch et al. 2001) have been raised for the past decade, with increasing periods of localised anoxic conditions and an increase in harmful algal blooms (Anderson et al. 2008), both of which have repercussions on shellfish harvest. The increase in nutrient loading from the watershed to the bay (Krembs 2013) together with the particular upwelling conditions along the US West Coast are amplifying both eutrophication and ocean acidification phenomena (Khangaonkar et al. 2012).

It is well established that shellfish aquaculture services regarding eutrophication symptoms are of interest for ecosystem restoration initiatives to 'protect and enhance a resource that is important for jobs, industry, citizens and tribes'. Clam culture provides the 4 ecosystem services as described by the Millennium Ecosystem Assessment (Millennium Ecosystem Assessment 2005, Maltby 2013): (1) food provisioning service, (2) regulating service for water clarity by reducing eutrophication symptoms, (3) supporting service for nutrient cycling and creating artificial reefs and (4) cultural service via tourism and recreational activities and from cultural heritage. The increase of farms using the Chuckanut approach, along with the creation of new jobs, holds promise both for industry development and eutrophication abatement.

However, the EAA includes not only production and ecological carrying capacity (Thrush et al. 2012, Ross et al. 2013), but also social and governance components (Inglis et al. 2000, McKindsey et al. 2006, Costa-Pierce 2008, Soto et al. 2008). Social acceptance for non-fed aquaculture has improved, for instance through eco-certification (Jonell et al. 2013), and together with the development of new culture technologies for sustainable aquaculture (Costa Pierce 2010), more initiatives for developing further shellfish aquaculture are emerging in developed countries where constraints are greater than in other parts of the world.

We hope that the analysis presented herein, based on a real farm with a genuine commitment to environmental stewardship, might help competitive users of waterfront resources, government agencies and stakeholders in general to better appreciate the role that sustainable shellfish culture plays in the provision of ecosystem goods and services.

Acknowledgements. The research received support from the NOAA Saltonstall-Kennedy Grant Program (FY10) grant number NA10NMF4270309. The authors are grateful to NOAA Saltonstall-Kennedy Grant Program for the monitoring data used in the study. The authors additionally thank 4 anonymous reviewers for comments on an earlier draft.

\section{LITERATURE CITED}

Anderson DM, Burkholder JM, Cochlan WP, Glibert PM and others (2008) Harmful algal blooms and eutrophication: 
examining linkages from selected coastal regions of the United States. Harmful Algae 8:39-53

Badino G, Bona F, Maffiotti A, Giovanardi O, Pranovi F (2004) Impact of mechanical clam harvesting on a benthic habitat: evaluation by means of sediment profile imaging. Aquat Conserv 14:S59-S67

Bendell LI, Duckham C, L'Espérance T, Whiteley JA (2010) Changes in geochemical foreshore attributes as a consequence of intertidal shellfish aquaculture: a case study. Mar Ecol Prog Ser 404:91-108

Boesch DF, Brinsfield RB, Magnien RE (2001) Chesapeake Bay eutrophication: scientific understanding, ecosystem restoration, and challenges for agriculture. J Environ Qual 30:303-320

Bricker SB, Clement CG, Pirhalla DE, Orlando SP, Farrow DRG (1999) National estuarine eutrophication assessment: effects of nutrient enrichment in the nation's estuaries. NOAA, National Ocean Service, Special Projects Office and the National Centers for Coastal Ocean Science. Silver Spring, MD

Bricker SB, Ferreira JG, Simas T (2003) An integrated methodology for assessment of estuarine trophic status. Ecol Modell 169:39-60

Bricker SB, Longstaf B, Dennison W, Jones A, Boicourt K, Wicks C, Woerner J (2008) Effects of nutrient enrichment in the nation's estuaries: a decade of change. Harmful Algae 8:21-32

Burkholder JM, Shumway SE (2011) Bivalve shellfish aquaculture and eutrophication, In: Shumway SE (ed) Shellfish and the environment. Wiley, New York, NY, p 155-215

Carlsson MS, Engström P, Lindahl O, Ljungqvist L, Petersen JK, Svanberg L, Holmer M (2012) Effects of mussel farms on the benthic nitrogen cycle on the Swedish west coast. Aquacult Environ Interact 2:177-191

Chew KK (1989) Manila clam biology and fishery development in western North America. In: Manzi JJ, Castagna $\mathrm{M}$ (eds) Clam mariculture in North America. Elsevier Press, New York, NY, p 243-261

Coen LD (1995) A review of the potential impacts of mechanical harvesting on subtidal and intertidal shellfish resources. South Carolina Department of Natural Resources. Available at www.ecsga.org/Pages/ Sustainability/Coen\%2095\%20review.pdf (accessed 15 October 2013)

Coen LD, Brumbaugh RD, Bushek D, Grizzle R and others (2007) Ecosystem services related to oyster restoration. Mar Ecol Prog Ser 341:303-307

Costa-Pierce B (2002) Ecology as the paradigm for the future of aquaculture. In: Costa-Pierce B (ed) Ecological aquaculture: the evolution of the blue revolution. Blackwell Science, Oxford, p 339-372

Costa-Pierce BA (2008) An ecosystem approach to marine aquaculture: a global review. In: Soto D, AguilarManjarrez J, Hishamunda N (eds) Building an ecosystem approach to aquaculture. FAO/Universitat de les illes Balears Expert Workshop, 7-11 May 2007, Palma de Mallorca, FAO Fisheries and Aquaculture Proceedings No. 14, Rome, p 81-116

Costa-Pierce BA (2010) Sustainable ecological aquaculture systems: the need for a new social contract for aquaculture development. Mar Technol Soc J 44:88-112

Cranford PJ, Hargrave BT, Doucette LI (2009) Benthic organic enrichment from suspended mussel (Mytilus edulis) culture in Prince Edward Island, Canada. Aquaculture 292:189-196
Crawford CM, Macleod CKA, Mitchell IM (2003) Effects of shellfish farming on the benthic environment. Aquaculture 224:117-140

> Dame RF, Prins TC (1997) Bivalve carrying capacity in coastal ecosystems. Aquat Ecol 31:409-421

Dealteris JT, Kilpatrick BD, Rheault RB (2004) A comparative evaluation of the habitat value of shellfish aquaculture gear, submerged aquatic vegetation and a nonvegetated seabed. J Shellfish Res 23:867-874

Defossez JM, Daguzan J (1995) Mesure comparative du débit palléal des bivalves Tapes decussatus et Ruditapes philippinarum lors de rapides changements de température et de turbidité. Cah Biol Mar 36:299-307

Dewey W, Davis JP, Cheney DP (2011) Shellfish aquaculture and the environment: an industry perspective. In: Shumway SE (ed) Shellfish aquaculture and the environment, Wiley, New York, NY, p 33-50

Dewey W, Shurbier AD, Ferreira JG, Cordell JR, Davis JP, Cheney DP (2013) Assessing the effects of mechanized Manila clam farming in North Puget Sound, Washington, USA. World Aquaculture Society Conference 2013Nashville, TN, USA, 21-25 February 2013

$>$ Droop MR (1970) Vitamin-B12 and marine ecology. Helgoländer wiss Meeresunter 20:629-636

> Dumbauld BR, Ruesink JL, Rumrill SS (2009) The ecological role of bivalve shellfish aquaculture in the estuarine environment: a review with application to oyster and clam culture in West Coast (USA) estuaries. Aquaculture 290:196-223

FAO (Food and Agriculture Organization of the United Nations) (2012) The state of world fisheries and aquaculture (SOFIA). FAO, Rome

> Ferreira JG, Hawkins AJS, Bricker SB (2007) Management of productivity, environmental effects and profitability of shellfish aquaculture - the Farm Aquaculture Resource - Management (FARM) model. Aquaculture 264: 160-174

Ferreira JG, Sequeira A, Hawkins AJS, Newton A and others (2009) Analysis of coastal and offshore aquaculture: application of the FARM model to multiple systems and shellfish species. Aquaculture 289:32-41

Ferreira JG, Hawkins AJS, Bricker S (2011) Chapter 1. The role of shellfish farms in provision of ecosystem goods and services. In: Shumway S (ed) Shellfish aquaculture and the environment. Wiley-Blackwell, Chichester, p 3-32

- Ferreira JG, Saurel C, Ferreira JM (2012) Cultivation of gilthead bream in monoculture and integrated multi-trophic aquaculture. Analysis of production and environmental effects by means of the FARM model. Aquaculture 358-359:23-34

Ferreira JG, Ramos L, Costa-Pierce BA (2013) Key drivers and issues surrounding carrying capacity and site selection, with emphasis on environmental components. In: Ross LG, Telfer TC, Falconer L, Soto D, Aguilar-Manjarrez J (eds) Site selection and carrying capacities for inland and coastal aquaculture. FAO/Institute of Aquaculture, University of Stirling, Expert Workshop, 6-8 December 2010, Stirling. FAO Fisheries and Aquaculture Proceedings No. 21, Rome, p 47-86

- Flye-Sainte-Marie J, Jean F, Paillard C, Ford S, Powell E, Hofmann E, Klinck J (2007) Ecophysiological dynamic model of individual growth of Ruditapes philippinarum. Aquaculture 266:130-143

Forrest BM, Keeley NB, Hopkins GA, Webb SC, Clement 
DM (2009) Bivalve aquaculture in estuaries: review and synthesis of oyster cultivation effects. Aquaculture 298: $1-15$

> Godet L, Toupoint N, Fournier J, Le Mao P, Retiere C, Olivier F (2009) Clam farmers and oystercatchers: effects of the degradation of Lanice conchilega beds by shellfish farming on the spatial distribution of shorebirds. Mar Pollut Bull 58:589-595

Godfray HCJ, Beddington JR, Crute IR, Haddad L and others (2010) Food security: the challenge of feeding 9 billion people. Science 327:812-818

Inglis GJ, Gust N (2003) Potential indirect effects of shellfish culture on the reproductive success of benthic predators. J Appl Ecol 40:1077-1089

Inglis GJ, Hayden BJ, Ross AH (2000) An overview of factors affecting the carrying capacity of coastal embayments for mussel culture. Client Report CHC00/69, National Institute of Water and Atmospheric Research (NIWA), Christchurch

> Jackson JBC, Kirby MX, Berger WH, Bjorndal KA and others (2001) Historical overfishing and the recent collapse of coastal ecosystems. Science 293:629-637

Jolly CM, Clonts HA (1993) Economics of aquaculture. Food Products Press, New York, NY

Jonell M, Phillips M, Ronnback P, Troell M (2013) Eco-certification of farmed seafood: Will it make a difference? Ambio 42:659-674

Jones C, Branoksy E, Selman M, Perez M (2010) 'How nutrient trading could help restore the Chesapeake Bay.' WRI Working Paper. World Resources Institute, Washington, DC. Available at http://pdf.wri.org/working_papers/how _nutrient_trading_could_help_restore_the_chesapeake_ bay.pdf (accessed 21 April 2014)

Kaiser MJ, Edwards DB, Spencer BE (1996) Infaunal community changes as a result of commercial clam cultivation and harvesting. Aquat Living Resour 9:57-63

Khangaonkar T, Sackmann B, Long W, Mohamedali T, Roberts M (2012) Simulation of annual biogeochemical cycles of nutrient balance, phytoplankton bloom(s), and DO in Puget Sound using an unstructured grid model. Ocean Dyn 62:1353-1379

Krembs C (2013) Eutrophication in Puget Sound. In: Irvine JR, Crawford WR (eds) State of physical, biological, and selected fishery resources of Pacific Canadian marine ecosystems in 2012. DFO Can Sci Advis Sec Res Doc 2013/032, Ottawa, 106-112. Available at www.dfo-mpo. gc.ca/Csas-sccs/publications/resdocs-docrech/2013/2013_ 032-eng.pdf (accessed 21 April 2014)

Lavoie M-F, McKindsey CW, Pearce CM Archambault P (2013) Assessing the influence of intertidal aquaculture of the Manila clam (Venerupis philippinarum) on biogeochemical fluxes. Poster at the AQUA2013 conference, Las Palmas, Gran Canaria, Spain, 2-7 November 2013

Lindahl O, Hart R, Hernroth B, Kollberg S and others (2005) Improving marine water quality by mussel farming: a profitable solution for Swedish society. Ambio 34: 131-138

> Maltby L (2013) Ecosystem services and the protection, restoration, and management of ecosystems exposed to chemical stressors. Environ Toxicol Chem 32:974-983

> McKindsey CW, Thetmeyer H, Landry T, Silvert W (2006) Review of recent carrying capacity models for bivalve culture and recommendations for research and management. Aquaculture 261:451-462

Merino G, Barange M, Blanchard JL, Harle J and others
(2012) Can marine fisheries and aquaculture meet fish demand from a growing human population in a changing climate? Glob Environ Change 22:795-806

Meybeck M, Chapman DV, Helmer R (1989) Global water quality: a first assessment. World Health Organisation/ United Nations Environment Programme. Basil Blackwell, Cambridge

Millennium Ecosystem Assessment (2005) Ecosystems and human wellbeing: synthesis. Island Press, Washington, DC. Available at www.millenniumassessment.org/ documents/document.356.aspx.pdf (accessed 21 April 2014)

Munroe D, McKinley RS (2007) Commercial Manila clam (Tapes philippinarum) culture in British Columbia, Canada: the effects of predator netting on intertidal sediment characteristics. Estuar Coast Shelf Sci 72:319-328

Newell RIE (2004) Ecosystem influences of natural and cultivated populations of suspension-feeding bivalve molluscs: a review. J Shellfish Res 23:51-61

> Nobre AM, Ferreira JG, Newton A, Simas T, Icely JD, Neves R (2005) Management of coastal eutrophication: integration of field data, ecosystem-scale simulations and screening models. J Mar Syst 56:375-390

Nunes JP, Ferreira JG, Bricker SB, O'Loan B and others (2011) Towards an ecosystem approach to aquaculture: assessment of sustainable shellfish cultivation at different scales of space, time and complexity. Aquaculture 315:369-383

Pacific Coast Shellfish Growers Association (2012) Shellfish production on the west coast. Available at http://pcsga. org/wprs/wp-content/uploads/2013/04/production_stats. pdf (accessed 25 August 2013)

Pollack JB, Yoskowitz D, Kim HC, Montagna PA (2013) Role and value of nitrogen regulation provided by oysters (Crassostrea virginica) in the Mission-Aransas Estuary, Texas, USA. PLoS ONE 8:e65314

Powers MJ, Peterson CH, Summerson HC, Powers SP (2007) Macroalgal growth on bivalve aquaculture netting enhances nursery habitat for mobile invertebrates and juvenile fishes. Mar Ecol Prog Ser 339:109-122

> Pranovi F, Libralato S, Raicevich S, Granzotto A, Pastres R, Giovanardi O (2003) Mechanical clam dredging in Venice lagoon: ecosystem effects evaluated with a trophic mass-balance model. Mar Biol 143:393-403

> Prins TC, Smaal AC, Dame RF (1997) A review of the feedbacks between bivalve grazing and ecosystem processes. Aquat Ecol 31:349-359

Ross LG, Telfer TC, Falconer L, Soto D and others (2013) Carrying capacities and site selection within the ecosystem approach to aquaculture. In: Ross LG, Telfer TC, Falconer L, Soto D, Aguilar-Manjarrez J (eds) Site selection and carrying capacities for inland and coastal aquaculture. FAO/Institute of Aquaculture, University of Stirling, Expert Workshop, 6-8 December 2010, Stirling. FAO Fisheries and Aquaculture Proceedings No. 21, Rome, p 19-46

Šegvić-Bubić T, Grubišić L, Karaman N, Tičina V, Jelavić KM, Katavić I (2011) Damages on mussel farms potentially caused by fish predation-self service on the ropes? Aquaculture 319:497-504

Shumway SE, Davis C, Downey R, Karney R and others (2003) Shellfish aquaculture - in praise of sustainable economies and environments. World Aquacult 34:15-17

Silva C, Ferreira JG, Bricker SB, DelValls TA, Martin-Diaz ML, Yanez E (2011) Site selection for shellfish aquacul- 
ture by means of GIS and farm-scale models, with an emphasis on data-poor environments. Aquaculture 318: 444-457

Smaal A, van Stralen M, Schuiling E (2001) The interaction between shellfish culture and ecosystem processes. Can J Fish Aquat Sci 58:991-1002

Sobral P, Widdows J (1997) Influence of hypoxia and anoxia on the physiological responses of the clam Ruditapes decussatus from southern Portugal. Mar Biol 127:455-461

Solidoro C, Pecenik G, Pastres R, Franco D, Dejak C (1997) Modelling macroalgae (Ulva rigida) in the Venice lagoon: model structure identification and first parameters estimation. Ecol Modell 94:191-206

Soto D, Aguilar-Manjarrez J, Brugère C, Angel D and others (2008) Applying an ecosystem-based approach to aquaculture: principles, scales and some management measures. In: Soto D, Aguilar-Manjarrez J, Hishamunda N (eds) Building an ecosystem approach to aquaculture. FAO/Universitat de les illes Balears Expert Workshop, 7-11 May 2007, Palma de Mallorca, FAO Fisheries and Aquaculture Proceedings No. 14, Rome, p 15-35

Spencer BE, Kaiser MJ, Edwards DB (1997) Ecological effects of intertidal Manila clam cultivation: observations at the end of the cultivation phase. J Appl Ecol 34: 444-452

Stephenson K, Aultman S, Metcalfe T, Miller A (2010) An evaluation of nutrient nonpoint offset trading in Virginia: a role for agricultural nonpoint sources? Water Resour Res 46:W04519, doi:10.1029/2009WR008228

Stirling D (2011) Mechanized clam harvesting for coastal British Columbia: environmental implications. MSc the-

Editorial responsibility: Alejandro Buschmann, Puerto Montt, Chile sis. University of Victoria

Thrush MA, Dunn PL, Peeler EJ (2012) Monitoring emerging diseases of fish and shellfish using electronic sources. Transbound Emerg Dis 59:385-394

Toupoint N, Godet L, Fournier J, Retiere C, Olivier F (2008) Does Manila clam cultivation affect habitats of the engineer species Lanice conchilega (Pallas, 1766)? Mar Pollut Bull 56:1429-1438

> Trainer VL, Cochlan WP, Erickson A, Bill BD, Cox FH, Borchert JA, Lefebvre KA (2007) Recent domoic acid closures of shellfish harvest areas in Washington State inland waterways. Harmful Algae 6:449-459

UN (2010) World population prospects: the 2010 revision. Department of Economic and Social Affairs. Population Division, New York, NY

Walne PR (1972) The influence of current speed, body size and water temperature on the filtration rate of five species of bivalves. J Mar Biol Assoc UK 52: 345-374

Wilbur AE, Seyoum S, Bert TM, Arnold WS (2005) A genetic assessment of bay scallop (Argopecten irradians) restoration efforts in Florida's Gulf of Mexico coastal waters (USA). Conserv Genet 6:111-122

> Worm B, Branch TA (2012) The future of fish. Trends Ecol Evol 27:594-599

> Worm B, Hilborn R, Baum JK, Branch TA and others (2009) Rebuilding global fisheries. Science 325:578-585

> zu Ermgassen PSE, Gray MW, Langdon CJ, Spalding MD, Brumbaugh RD (2013) Quantifying the historic contribution of Olympia oysters to filtration in Pacific Coast (USA) estuaries and the implications for restoration objectives. Aquat Ecol 47:149-161

Submitted: December 27, 2013; Accepted: August 4, 2014 Proofs received from author(s): October 12, 2014 